УДК 902/903

https://doi.org/10.24852/2587-6112.2021.6.156.170

\title{
ХАРАКТЕРИСТИКА НЕОЛИТА СЕВЕРНОЙ АФРИКИ
}

\section{() 2021 г. С. Си-Аммур, Л.Ф. Недашковский}

НеолитСеверной Африкиявляетсяпредметомдолгих дискуссийспециалистовпосредиземноморскому неолиту, он остается пока сравнительно слабо изученным из-за основного внимания к неолитизации в Сахаре и характеристике аккультурации в других местах. Последовательность основных работ, созданных французскими учеными и энтузиастами начиная с 1868 г., позволяет нам по мере развития знаний добавлять фрагменты в мозаику неолитического периода и дает возможность представить целостную картину неолитической экономики и культурного разнообразия посредством изучения траекторий их распространения. Цель данной статьи - дать обзор основных научных результатов, полученных за последнее столетие, представив систематизацию неолита Северной Африки, классифицировав различные неолитические традиции, присутствовавшие в северо-западной части Африканского континента (средиземноморский неолит, капсийская неолитическая традиция и сахарскосуданский неолит), приводя основные характеристики каждой неолитической традиции.

Ключевые слова: археология, неолит, территориальные группы, Северная Африка.

\section{CHARACTERISTICS OF THE NORTH AFRICAN NEOLITHIC}

\section{S. Si-Ammour, L.F. Nedashkovsky}

The North African Neolithic is the subject of long debates among specialists in the Mediterranean Neolithic, and has remained relatively understudied due to the primary focus on Neolithization in the Sahara and the characteristics of acculturation in other areas. A series of major works undertaken by French researchers and enthusiasts since 1868 had allowed, as our knowledge expanded, to add pieces to the Neolithic horizon puzzle, and to develop a global vision of the Neolithic economy and cultural diversity by studying the trajectories of their diffusion. The aim of this paper is to provide an overview of the main research results obtained over the last century by suggesting a systematization of the Neolithic in North Africa, categorizing the various Neolithic traditions present in the north-western part of the African continent (Mediterranean Neolithic, Neolithic of Capsian tradition and Saharo-Sudanese Neolithic), outlining the main characteristics of each Neolithic tradition.

Keywords: archaeology, Neolithic, territorial groups, North Africa.

В период неолита человечество преуспело в создании сети поселений и управлении окружающей средой в соответствии со своими потребностями. Предположительно это связано с глобальным потеплением климата, произошедшим с окончанием последнего оледенения и обеспечившим лучшие условия жизни для человечества, которое было познавательно готово к инновациям и экспериментам с новыми образами жизни. Люди использовали участки земли для сельского хозяйства, отбирали благоприятные виды животных для приручения, создали керамику и часто использовали полированные каменные орудия наряду с традиционными изделиями в ударной технике. Эти характеристики представляют собой основные черты полной неолитизации, которая проявилась в разных частях мира в разных формах. Период неолита впервые был выделен как эпоха полированных каменных орудий, характеризующаяся появлением наконечников стрел, керамики, земледелия и скотоводства. Затем появилась концепция «неолитической революции», которая рассматривалась как серьезные изменения в человеческом поведении, подразумевающие переход от экономики охотников-собирателей к оседлому производящему хозяйству (Balout, 1955, 1972; Zammit, 1984; Aumassip, 1997a, 2001; Senecal, 2010; Lemercier, 2007). Современные взгляды на проблему неолита связаны с концепцией управления человеком природой, включая контроль над фауной и флорой (Aumassip, 1997b, 2001; Lemercier, 2007). Человечество освоило возможности в производстве ресурсов и занялось одомашниванием животных, земледелием, стало жить в сельских поселениях, использовать керамические сосуды, изготавливать сложные полированные орудия, наконечники стрел, изделия из кости, а также предметы искусства. Каменные индустрии часто ассоциируются 


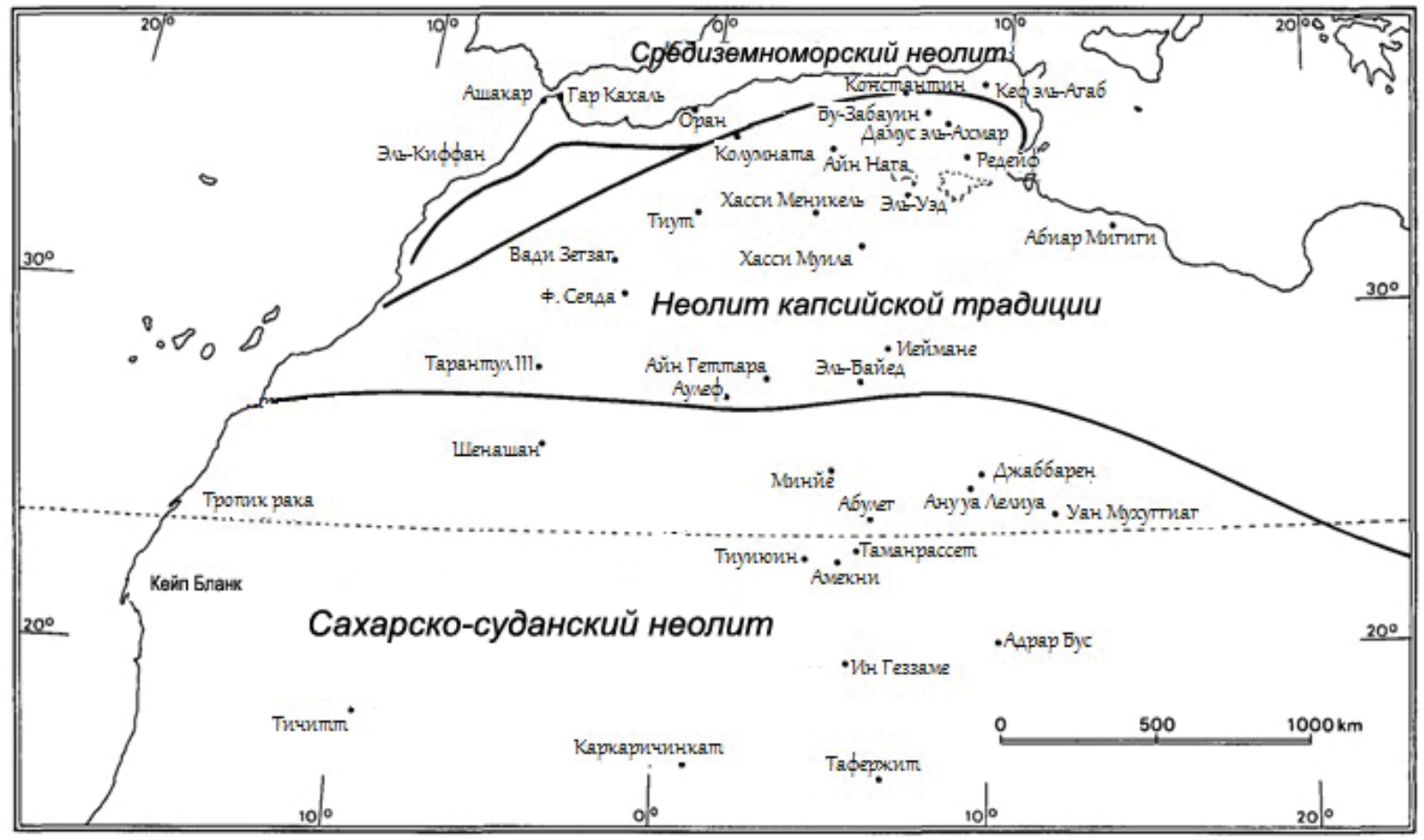

Рис. 1. Карта неолитических зон Северной Африки (по: Camps, 1982, p. 554, fig. 8,1; с изменениями).

Fig. 1. Map of the Neolithic areas of North Africa (after: Camps, 1982, p. 554, fig. 8.1; as amended).

с полированными топорами, теслами, терочниками и зернотерками, дополняемыми ранее известными орудиями, такими как геометрические микролиты, резцы, скребки и другие образцы бифасиальной техники (Balout, 1955, 1972; Zammit, 1984; Aumassip, 1997b, 2001; Lemercier, 2007).

Исследования в Северной Африке позволили предположить существование трех неолитических зон; первая находится в регионах Сахары, вторая - в Северной Сахаре и горных северных регионах, а последняя - вдоль побережья Средиземного моря, где большинство стратифицированных памятников располагается в пещерах и убежищах (рис. 1). В последующем кратком обзоре мы попытались описать основные неолитические особенности каждого региона и дать их хронологию. Мы также описали различные зоны североафриканского неолита: сахарскосуданский неолит, неолит капсийской традиции и средиземноморский неолит.

Сахарско-суданский неолит (9600-2000 л. н.)

Сахарско-суданский неолит охватывает территорию между югом Сахары и экваториальными лесами, в дополнение к неолиту долины Нила (рис. 2). Сначала он считался продолжением суданского неолита и назывался «неолитом суданской традиции», главным образом потому, что в то время самые ранние даты относились к Леванту и Судану (Шахейнаб), а формальное видение заключалось в том, что распространение неолита происходило только из плодородного полумесяца (De Contenson, 1971; Camps, 1974; Hendrickx, 1999). Но по мере развития науки радиоуглеродное датирование дало синхронные даты с египетскими и суданскими неолитическими памятниками. Название «традиция» перестало употребляться после того как ранние радиоуглеродные даты выявили синхронность памятников Сахары и суданских берегов Нила, датировав неолит Сахары временем с начала VIII тыс. до н.э. Это побудило Г. Кэмпса предложить название «сахарско-суданский неолит» в 1957 г. Конечно, не отделяя регион Сахары от суданской культуры, поскольку влияния и контакты могут быть доказаны, особенно на стадии приручения овец и быков. Однако даже когда более ранние даты были позже опубликованы (Эль Адам), никто не отверг предложение Г. Кэмпса и сохранилось название «сахарско-суданский неолит» 


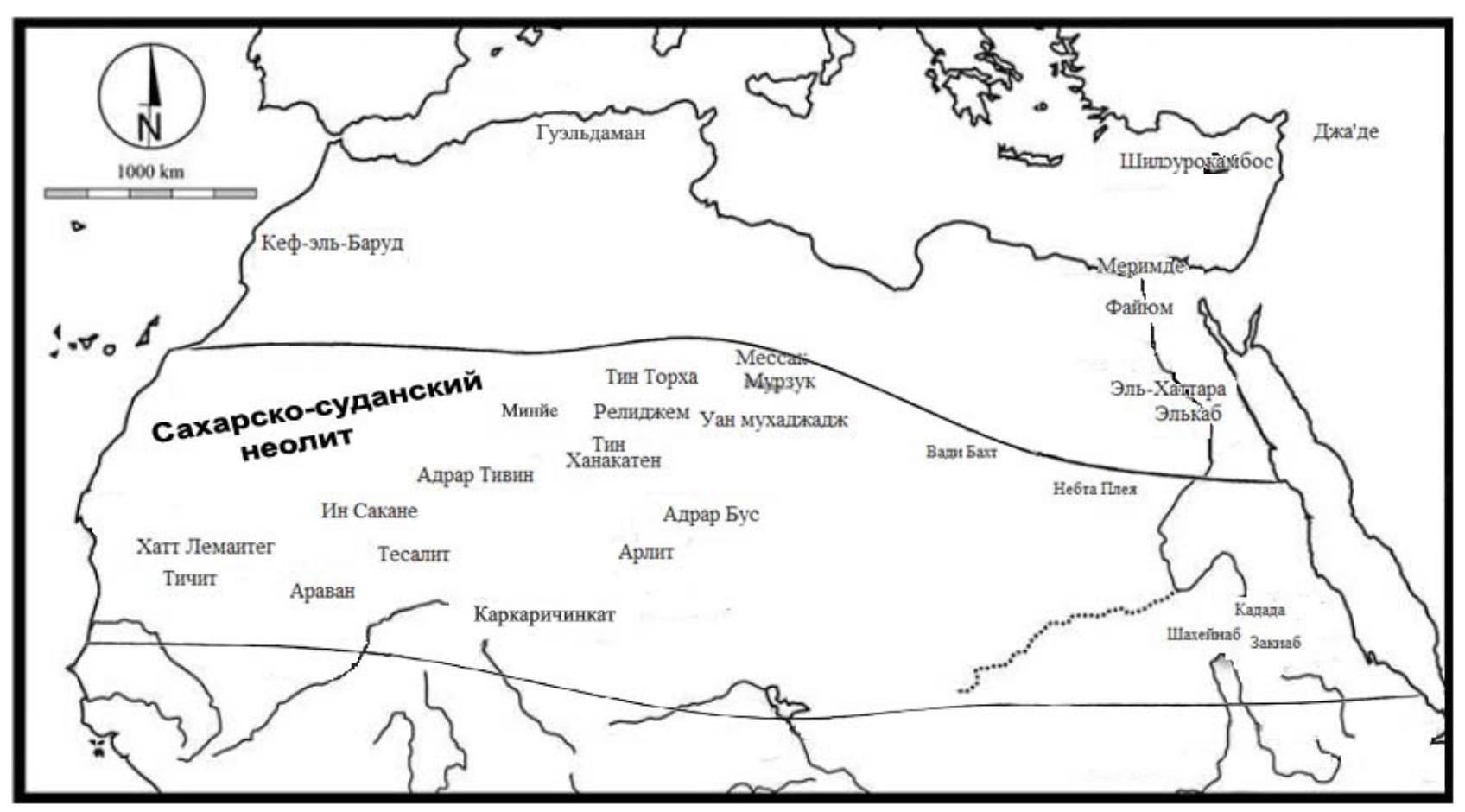

Рис. 2. Карта памятников сахарско-суданского неолита (по: Le Quellec 2013, p. 21, fig. 10; с изменениями) Fig. 2. Map of the sites of Saharo-Sudanese Neolithic (after: Le Quellec, 2013, p. 21, fig. 10; as amended).

(Balout, 1955; Chavaillon, 1964; De Contenson, 1971; Camps-Fabrer, Camps, 1972, Camps, 1974, 1982; Aumassip, 1984; Hassan, 1986; Hendrickx, 1999; Sahed, 2014; Hachid, 2015).

Имеются следующие датировки для памятников сахарско-суданского неолита.

ЕГИПЕТ: Эль Адам $9820 \pm 380,9610$, Лагерь Вильманна $8860 \pm 300$, Фаюм (А) 6440 ${ }^{14} \mathrm{C}$ л. н.

СУДАН: Хартум 6000 ВР, Шахейнаб (Хартум) $8000{ }^{14} \mathrm{C} \mathrm{л.} \mathrm{н.}$

АЛЖИР: Хоггар-Лони $9210 \pm 115{ }^{14}$ С л. н., Амекни $8720{ }^{14} \mathrm{C}$ л. н.

ЛИВИЯ: Тадрарт Акакус $8120{ }^{14} \mathrm{C}$ л. н., Титераст Н'Эллиас $7450{ }^{14} \mathrm{C}$ л. н., Уан-Табу $7095{ }^{14} \mathrm{C}$ л. н.

НИГЕР: Айр-Темет $9550 \pm 100{ }^{14}$ С л. н., Тагалагал $9330 \pm 130{ }^{14} \mathrm{C}$ л. н., Эннеди-Дельбо $7230{ }^{14}$ C л. н. (Camps, 1974; Hendrickx, 1999; Garcea, 2020).

Чтобы лучше понять большую длительность существования неолита в Сахаре, мы должны сначала взглянуть на преобладающий климат в то время, чтобы понять, как климат и окружающая среда повлияли на поведение человека. Исследователи считают, что в конце позднего плейстоцена между 18000 и 13000 гг. до н.э. имела место сильная засуха, что вызвало массовый исход населения из регионов Сахары. Эти аридные явления, связанные с максимумом последнего оледенения, изменили региональные климатические биотопы Сахары, заставив некоторые группы охотников-собирателей адаптироваться к засушливым условиям окружающей среды, или приняв кочевой скотоводческий образ жизни, или сохранив прежний охотничий, следуя за животными по путям их миграций. И только после возвращения влажного климата в период позднего дриаса около 8500 г. до н.э. начали появляться первые преднеолитические поселения, что позволило неолитическим культурам процветать вплоть до постепенного упадка, начавшегося в V тыс. до н.э. из-за аридизации климата (рис. 3), приведшей к опустыниванию Сахары со II тыс. до н.э. (Guo et al., 2000; Aumassip, 1997b; Hendrickx, 1999; Vernet, 2004).

Период молодого дриаса длился около 5000 лет, климат между 7000 и 5500 гг. до н.э. характеризовался постоянными дождями, которые значительно изменили ландшафт. Также между 5500 и 5000 гг. до н.э. имел место короткий засушливый период (рис. 4), который гипотетически побудил население заняться скотоводством. В центральных реги- 


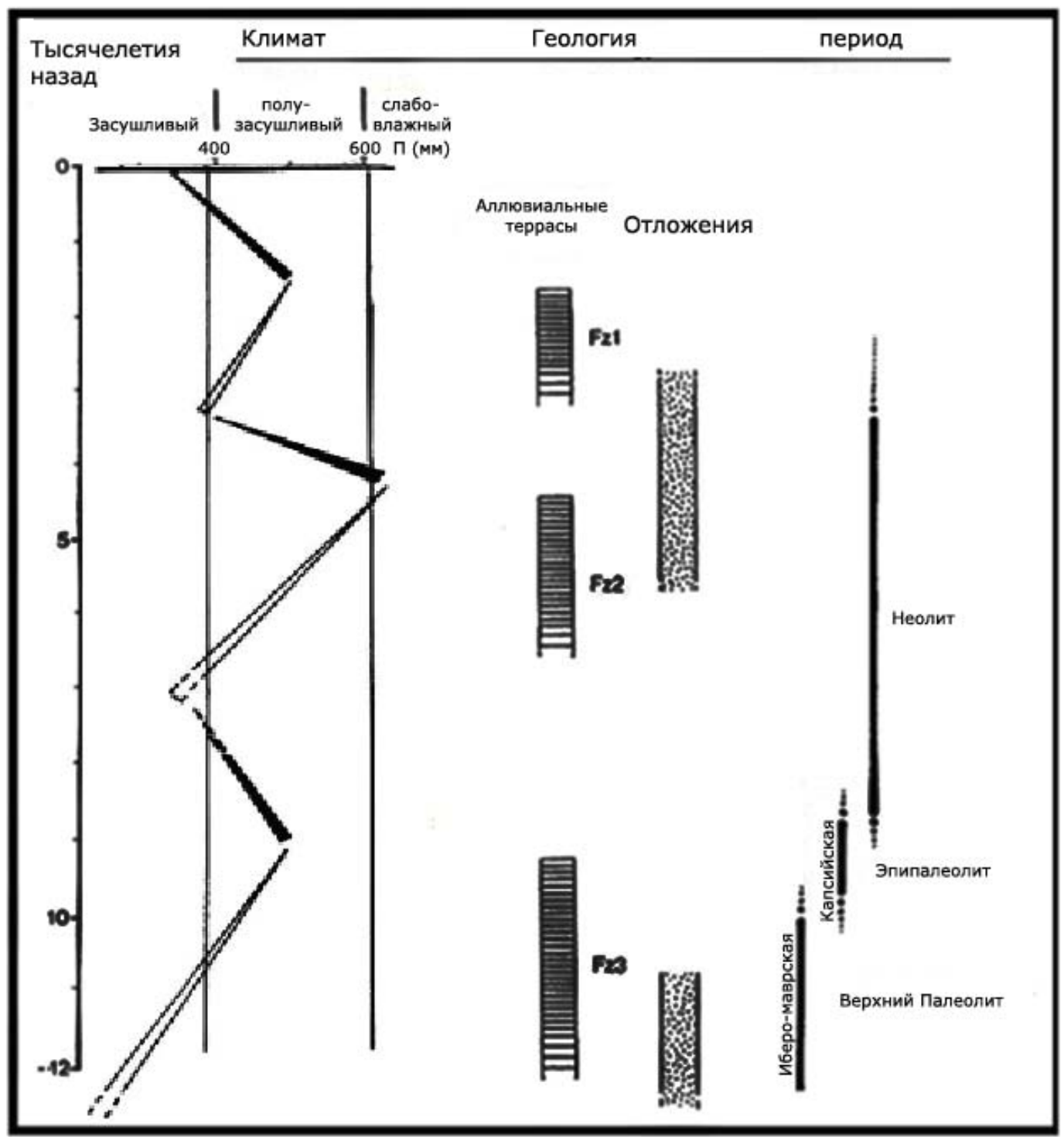

Рис. 3. Хронология послеледниковых климатических явлений в Северной Африке, показывающая влажные и сухие фазы (по: Wengler et al., 1994, p. 132, fig. 10; с изменениями).

Fig. 3. Chronology of the post-glacial climatic events in North Africa,

indicating the humid and arid phases (after: Wengler et al., 1994, p. 132, fig. 10; as amended)

онах было много озер и болот, длинные реки орошали западные регионы, а гидростатический уровень Восточного Эрга постоянно повышался (Guo et al., 2000; Aumassip, 1997b). В Сахаре по-прежнему сохранялся влажный климат, длинные реки и большие водные просторы, разбросанные между южной Мавританией и Чадом, проходили через долину Сауры, нагорье Ахаггар и плато ТассилинАдджер. Озера, которые могли иногда достигать глубины 10 метров, питались длинными полноводными реками, орошавшими Сахару (Camps, 1974, 1982). Биотопы изменились с пустынных на лесостепные и саванные, травянистые большие водоемы, которые привлекали животных и, следовательно, охотников, которые селились в горах, а также на берегах озер и рек (Vernet, 2004; Camps, 1974). Люди занимались охотой, рыболовством, скотоводством, собирательством и примитивным земледелием. Наличие озер благоприятствовало не только охоте в бассейнах рек, но также земледелию и отлову животных для экспериментов по их приручению и разведению (Camps, 1974). Возвращение поселений после молодого дриаса спровоцировало улучшение климатических условий: пыльца горных деревьев, таких как каменный дуб, грецкий орех, мастиковое дерево, каркас и можжевельник, свидетельствует о влажном климате (CampsFabrer, Camps, 1972; Aumassip, 1997; Vernet, 2004).

Неолитические племена, которые расселились в данной среде лесостепи и саванн, были 
идентифицированы как суданцы и представители этнической группы фульбе (фулани). Скелеты, найденные в погребениях Амекни, выявили антропологические характеристики, которые все еще присутствуют в нынешних популяциях пастухов туарегов, которые все еще живут в районе Амекни (De Contenson, 1971; Camps, 1974). Останки мехтоидов были обнаружены в южной и восточной части алжирской Сахары, а протосредиземноморцы были найдены смешанными с суданцами и фульбе (фулани) в ранненеолитических материалах Ахаггара, без каких-либо данных о природе контактов (Aumassip, 1984).

\section{Характеристика сахарско-суданского неолита}

Сахарско-суданский неолит характеризуется керамикой, представленной большими шаровидными горшками с округлым дном, обычно темными из-за плохого обжига и практически полностью покрытыми различными орнаментами, преимущественно пунктирными линиями (Camps, 1974, 1981; Aumassip, 2004). Некоторые орнаменты вырезаны кремневыми лезвиями или отщепами, а также представляют собой оттиски пальцев и побегов растений, также как костяных изделий, таких как гребни и проколки (Camps-Fabrer, 1966; Camps, 1974, 1982; Camps-Fabrer, Camps, 1972; Aumassip, 2004). Каменная индустрия преимущественно представлена пластинчатыми отщепами, наконечниками стрел, дисками, зернотерками и пестами. Показатель разнообразия каменных орудий в Ахаггаре очень низкий; в других местах оно богаче с замечательными изящными наконечниками стрел (Camps, 1974, 1981; Aumassip, 2004). Костяные орудия преимущественно связаны с рыболовством. Орудия рыбной ловли в основном представлены гарпунами и крючками из камня, кости и слоновой кости (Camps, 1974, 1981). Разнообразные украшения представлены бусами из скорлупы страусиных яиц, бусинами из амазонита, каменными кольцами и костяными подвесками (рис. 4) (Camps, 1974).

Произведения искусства, такие как наскальные рисунки, каменные и керамические фигурки, связаны с сахарскими бовидийской и тенерийской культурами. На рисунках и петроглифах представлены растения (пальмы), животные (муфлоны, антилопы, круп- ный рогатый скот, газели, жирафы, слоны, собаки, грызуны и рыбы). Изображения человека имеются в обрядовых и скотоводческих сценах (Camps, 1974, 1981, 1982; Vernet, 2004; Aumassip, 2004). Мы также должны упомянуть плетение корзин в Тин Ханакатене (Тассилин-Адджер) около 6800 г. до н.э. (Amassip, 1997b). Этнически носители традиции идентифицируются как суданцы и фульбе (фулани) в центральной и южной Сахаре (Camps 1974, 1981), смешанные с протосредиземноморцами в Ахаггаре и с некоторыми мехтоидами в юго-восточной Сахаре без каких-либо сведений о природе контактов (Aumassip, 1997b).

Отсутствие доказательств существования земледелия в основном связано с плохим состоянием сохранности археоботанических остатков. Единственные следы использования растений относятся к III тыс. до н.э. и представляют собой свидетельства сезонного сбора плодов дерева каркас (Celtis), а также предположения, основанные на данных спорово-пыльцевого анализа, указывающие на возможную деятельность по очистке земель на берегах озер (Амекни) для сбора возделывавшихся дикорастущих растений, таких как дикое просо (Pennisetum americanum, Pennisetum mollissimum). Другие данные также были получены в результате анализа керамических примесей-отощителей, смешанных с остатками колосьев проса, связанными со многими зернотерками и терочниками, указывающими на размол зерна. Это ясно указывает на выращивание или, по крайней мере, на употребление дикорастущих растений, но ничто не подтверждает какие-либо попытки доместикации растений в надлежащем земледельческом контексте (Camps, 1974, 1981, 1982; Aumassip, 1997b, 2004). Большинство данных об одомашнивании животных связано с наскальными рисунками, на которых изображены в основном одомашненные туры (Bos africanus), позднее другие животные, такие как овцы и козы, а в более поздний период лошади и верблюды. Также подтверждено, что в эпоху бовидийского наскального искусства группы людей (носители бовидийской и тенерийской культур) вели скотоводческий образ жизни, их наскальное искусство и мелкая пластика преимущественно представляют собой изображения домашних животных. Одомашнивание животных считается позд- 


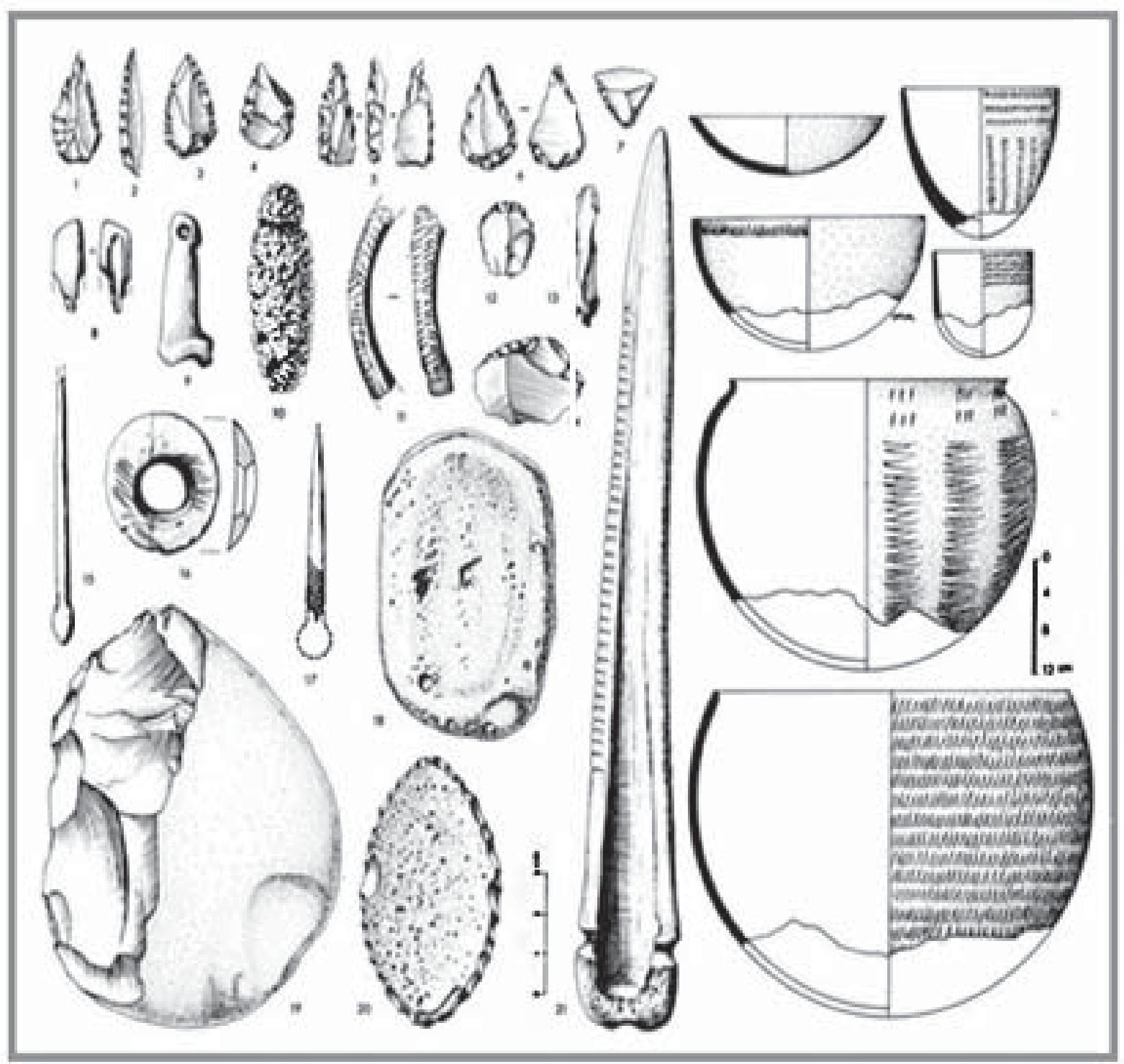

Рис. 4. Археологические находки сахарско-суданского неолита с поселения Амекни (по: Camps, 1982, p. 560-561, fig. 8,2-3; с изменениями).

Fig. 4. Archaeological finds of the Saharo-Sudanese Neolithic from the site of Amekni (after: Camps, 1982, p. 560-561, fig. 8.2-3; as amended).

ним, имеющиеся даты около 3550 г. до н.э. в Джаббарене и 3070 г. до н.э. в Сафаре (Camps, 1974, 1981, 1982; Aumassip, 2004; Bencherif, 2011; Honoré, 2014; Hachid, 2015).

Неолит капсийской традиции (7500-2000 л. н.)

Неолит капсийской традиции ограничен областью к югу от нагорий Магриба до тропика Рака, включая южные склоны Телля, Высокие плато, Сахарский Атлас, Триполитанию, Киренаику и север Сахары (рис. 5) (Camps, 1982). Неолитические инновации были сравнительно поздно включены в эпипалеолитический образ жизни Северо-Восточного Магриба путем добавления отдельных неолитических черт к капсийской традиции населения (Balout, 1955; Camps et al., 1968; Rahmani,
2003). Замечательные каменные индустрии Сахарского Атласа и северной Сахары, разнообразная костяная индустрия (рис. 6), использование страусиных яиц в качестве контейнеров чаще керамики, а также петроглифы и статуэтки являются наиболее характерными чертами этой неолитической культуры (Camps, 1974).

На ранних этапах исследований ученые столкнулись с трудностями в определении подходящего названия для неолита данного региона. С. Гселл описал распространение неолита в северной и нижней Сахаре, указав на присутствие двух неолитических волн, одной на севере (включая капсийский регион), названной им «пещерным неолитом», и одной на юге Сахарского Атласа, описан- 


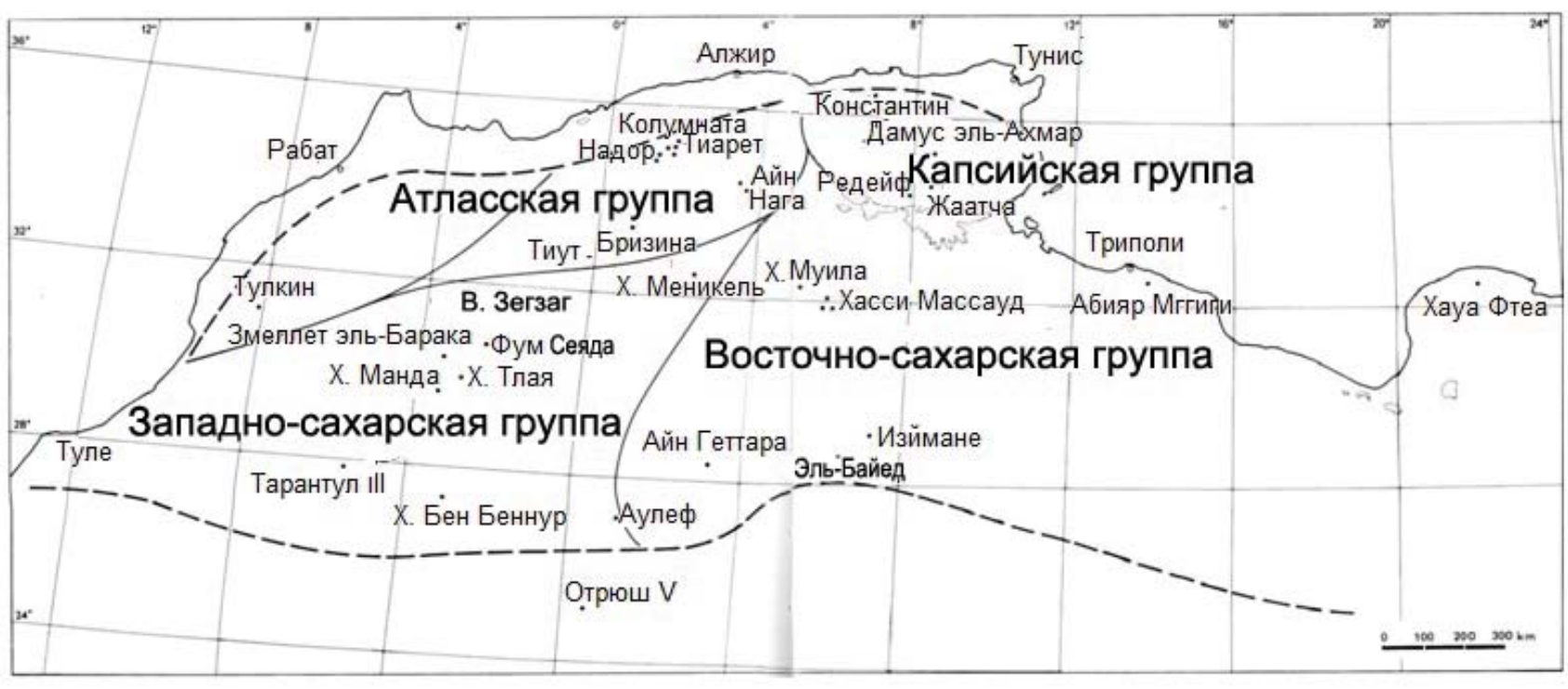

Рис. 5. Территориальные группы неолита капсийской традиции (по: Camps, 1974, p. 296-297, fig. 86; с изменениями).

Fig. 5. Neolithic territorial groups of the Capsian Tradition (after: Camps, 1974, p. 296-297, fig. 86; as amended).

ной как «неолит Сахары», а позднее известной как сахарский неолит капсийской традиции. В 1933 г. Р. Вофри предложил название «неолит капсийской традиции», основываясь на своих исследованиях в восточном регионе Магриба (Гафса, Тунис), где он выявил типичные капсийские черты (большие острия, долота, орудия на пластинах, скребки, пластины с односторонней ретушью, геометрические микролиты), в дополнение к специфически неолитическим элементам, таким как наконечники стрел, полированные топоры, ножи и керамика (Gsell, 1918; Balout, 1955; Camps, 1974, 1982). Р. Вофри склонялся к идее о широком распространении этого неолита из восточного региона в другие районы Северной Африки, в северную Сахару и Сахарский Атлас (Айн Геттара, Хасси Муила, Уаргла) (Balout, 1955; Camps, 1974; Roubet, 1979; Sahnouni, 1999). Но результаты исследований К. Рубе показали, что неолит капсийской традиции восточного региона фактически представляет собой только локальный горный вариант, датировки которого показали, что неолит был привнесен в восточный регион намного позже, чем в другие (Balout, 1955, 1972; Camps, 1974; Roubet, 1979), неолитические черты медленно проявились благодаря проникновению новых орудий и технических новшеств (полировка камня, наконечники стрел, керамика).
Название «неолит капсийской традиции» также вводит в заблуждение, потому что оно указывает на прямое капсийское влияние; на самом же деле «капсийская традиция» не является показательной для всех неолитических культур в этом регионе из-за подтвержденного присутствия иберо-маврской культуры в северных районах. Это побудило Г. Кэмпса предложить более продуманное региональное название «Атласско-Сахарский неолит» (Camps, 1974). К. Рубе (Roubet, 1979) предложил название «неолит капсийской традиции sensu strictu», исключительно относящееся к капсийскому району (Восточный Магриб), поскольку он точно показывает особенности, описанные Р. Вофри. И даже если другие регионы не находились под влиянием восточного района, они были включены в неолитическую капсийскую традицию из-за наличия эпипалеолитического капсийского субстрата под неолитическими слоями (Balout, 1972; Roubet, 1979; Camps, 1982).

Характеристика неолита капсийской традиции

Для данного неолита характерна керамика с яйцевидным туловом и коническим дном, у одних сосудов шейка открытая, у других закрытая. Орнаменты ограничиваются рядом рубцов по краю венчика и геометрическими мотивами из грубых вдавлений (оттисков в виде полумесяцев, клиньев, кругов), некоторые сосуды не имеют никакого орнамен- 


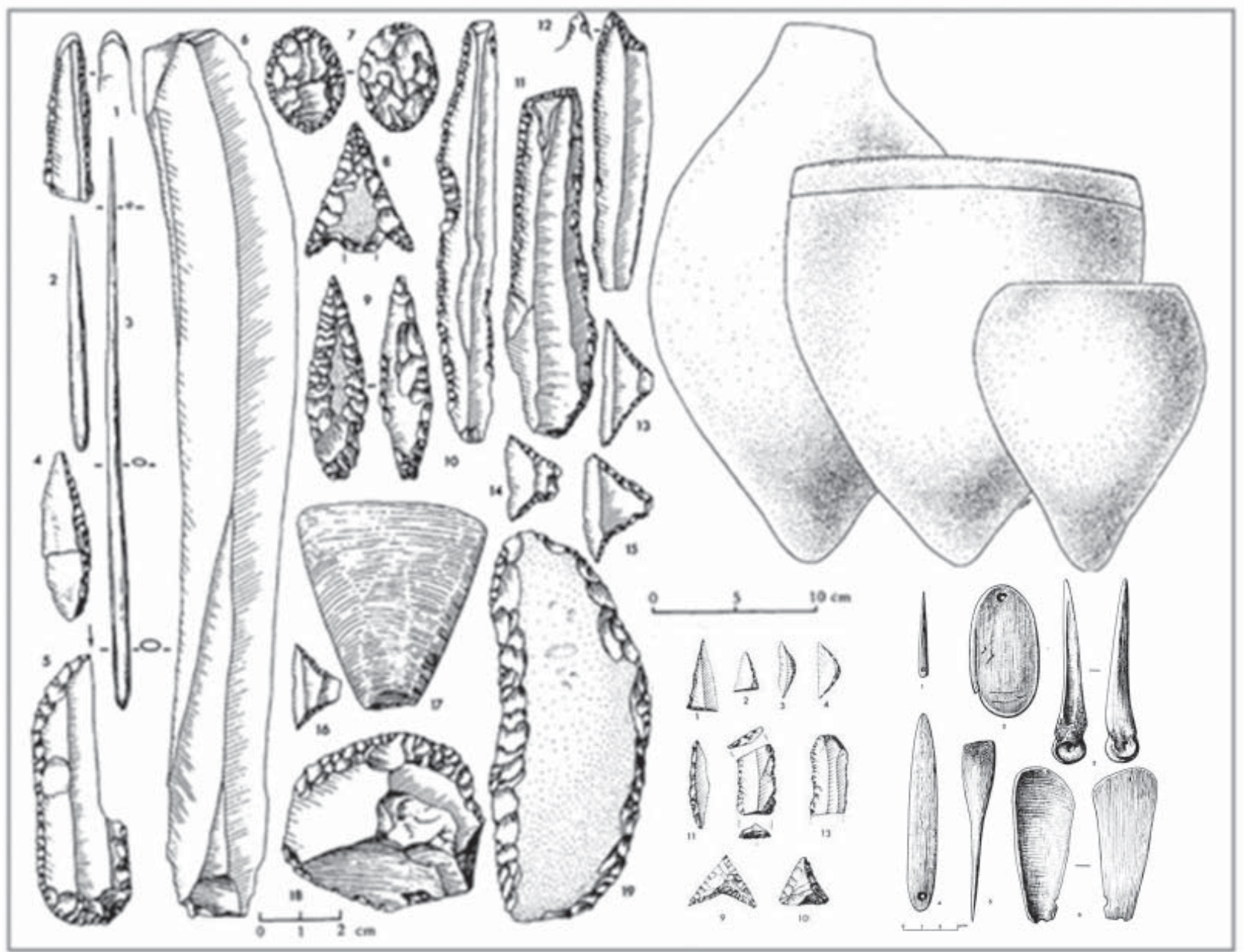

Рис. 6. Археологические находки неолита капсийской традиции «sensu strictu» из Дамус эль-Ахмар (по: Camps, 1974, p. 285-288, fig. 84-87; с изменениями)

Fig. 6. Archaeological finds of the Neolithic of the Capsian Tradition "sensu strictu" from Damous el-Ahmar (after: Camps, 1974, p. 285-288, fig. 84-87; as amended).

та. Орнаменты наносились путем вдавления стеблей растений для получения узоров в виде полумесяца, с помощью костяных изделий (проколки, гребни) для получения линий и ямочных вдавлений (Camps, 1974; Roubet, 1979; Aumassip, 1986) и даже веревок для получения их оттисков на керамике нижней Сахары; некоторые сосуды имеют ручки (Camps-Fabrer, 1966).

Отмечаются значительные добавления к эпипалеолитической каменной индустрии (поздний капсийский горизонт), неолитические признаки появляются постепенно вплоть до их окончательного утверждения. Комплекс каменных орудий состоит из типичных капсийских выемчатых и зубчатых орудий, пластин с ретушью, сверл, долот, геометрических микролитов (трапеций, наконечников стрел с прямым расширяющимся лезвием), а также характеризуется появлением новых неолитических орудий: полированных топоров, новых форм скребков, больших лезвий и шлифовальных инструментов. Костяная индустрия в целом хорошо сохранилась в пещерах, она состоит из всех известных форм проколок и булавок (рис. 6), отсутствуют только гарпуны. Ложки и шпатели использовались в качестве орудий для изготовления керамики, также как ножи и лощила. Также предполагается использование охры для раскраски тела. Скорлупа страусиных яиц использовалась для изготовления бус, а целая применялась в качестве контейнеров, которые часто украшались геометрическими узорами и изображениями животных, они заменяли керамику и служили для хранения семян и жидкостей (Aumassip, 2001; Kandel, Conard, 2005).

Изобразительное искусство (изображения на скалах и скорлупе страусиных яиц) представлено реалистичным стилем и субреа- 
листичным стилем «Тазина» (Camps, 1974), зародившемся в капсийской культуре и процветавшем в период неолита (Roubet, 1979). Темы изобразительного искусства гораздо больше сосредоточены на диких, а не на домашних животных, а геометрические узоры в основном встречаются на керамике и страусиных яйцах (Camps, 1974; Aumassip, 1986). Протосредиземноморский тип был широко распространен и некоторые мехтоиды присутствовали в горных хребтах северной капсийской зоны, а представители экваториальной расы также присутствовали в южных областях (Camps, 1974).

Нет четких свидетельств земледельческой деятельности в капсийском регионе (Roubet, 1979; Bahn, 1982), поскольку люди, вероятно, вели охотничье и полукочевое скотоводческое хозяйство (Balout, 1972; Honoré, 2014), их растительная диета была основана на сборе фруктов, различных дикорастущих растений, семян и желудей каменного дуба. Орудия помола показали первые свидетельства производства манной крупы в регионе; сладкие желуди каменного дуба заменили пшеницу и ячмень в качестве сырья для изготовления муки в начале IV тыс. до н.э. (Roubet, 1979). Об одомашнивании животных свидетельствуют костные остатки крупного рогатого скота, овец и свиней. На наскальных рисунках и страусиных яйцах преимущественно представлены изображения домашних животных, таких как овцы, козы и туры (Camps, 1974, 1981; Roubet, 1979; Hachid, 2015).

\section{Сахарский неолит капсийской традиции} (7500-2000 л. н.).

Нижняя Сахара занимает северную часть пустыни (рис. 5) и дает неолитические материалы, в которых роль керамики и полированных орудий невелика (Aumassip, 1986, 1991). Они имеют сходство на севере с неолитической капсийской традицией восточных регионов, показывают внешнее влияние из региона центральной Сахары (Хоггар), а также, возможно, из районов к востоку от Нила (Camps, 1974, 1982; Aumassip, 1986, 1991). Этот неолит распространился с середины VI тыс. до н.э. и характеризовался открытыми стоянками и особой каменной индустрией (Camps, 1974, 1982). Они использовали технику отжима для изготовления лезвий, пластин и геометрических микролитов. Капсийская традиция отмечена зубчатыми орудиями с выемками и пилками, которые являются типичными поздними капсийскими чертами (Rahmani, 2003).

О неолитическом характере индустрии свидетельствует высокий уровень изготовления и увеличение размеров таких орудий как скребки, геометрические микролиты, пилки, появление новых форм наконечников стрел, полированных орудий, инструментов для помола и керамики (Camps, 1974, 1982; Aumassip, 1986, 1991). Наскальное искусство чаще изображает диких, чем домашних животных (рис. 7). Геометрические орнаменты на страусиных яйцах широко распространены и подчеркивают преемственность с популяциями эпипалеолита (Camps, 1974; Aumassip, 2001). В некоторых регионах отмечается большое чувство эстетики и стабильности при изготовлении основных орудий (Aumassip, 1986).

\section{Средиземноморский неолит (8000-3600 л. н.). \\ Средиземноморский неолит распростра-} нялся вдоль всего побережья Магриба (рис. 8), он представлен двумя основными культурами: «неолитом Телля», который простирался от побережья Туниса до западного побережья Алжира, и «марокканским неолитом», взаимодействовавшим с культурой кардиальной керамики Пиренейского полуострова (Balout, 1955; Camps, 1974; Sahed, 2014). Ранние даты различных средиземноморских неолитических памятников свидетельствует о синхронности развития средиземноморского неолита, сложившегося около 5600-5500 гг. до н.э. (Camps, 1998; Linstadter et al., 2012; Mulazzani et al., 2015).

Переход к неолиту в регионе Телля (Тунис, Алжир) произошел в начале VI тыс. до н.э. (Кристель, Оран, $7810{ }^{14} \mathrm{C}$ л. н.) в результате контактов с неолитическим населением других территорий. Местное развитие неолита было основано на усилении неолитических черт, что также могло быть результатом торговли и обмена орудиями, сырьем, полированными топорами, керамикой, украшениями. Присутствие обсидиана с островов Липари и Пантеллерия подтверждает идею о существовании культурного влияния (Camps, 1974, 1998; Mulazzani et al., 2010, 2015; Freund, 2017). 


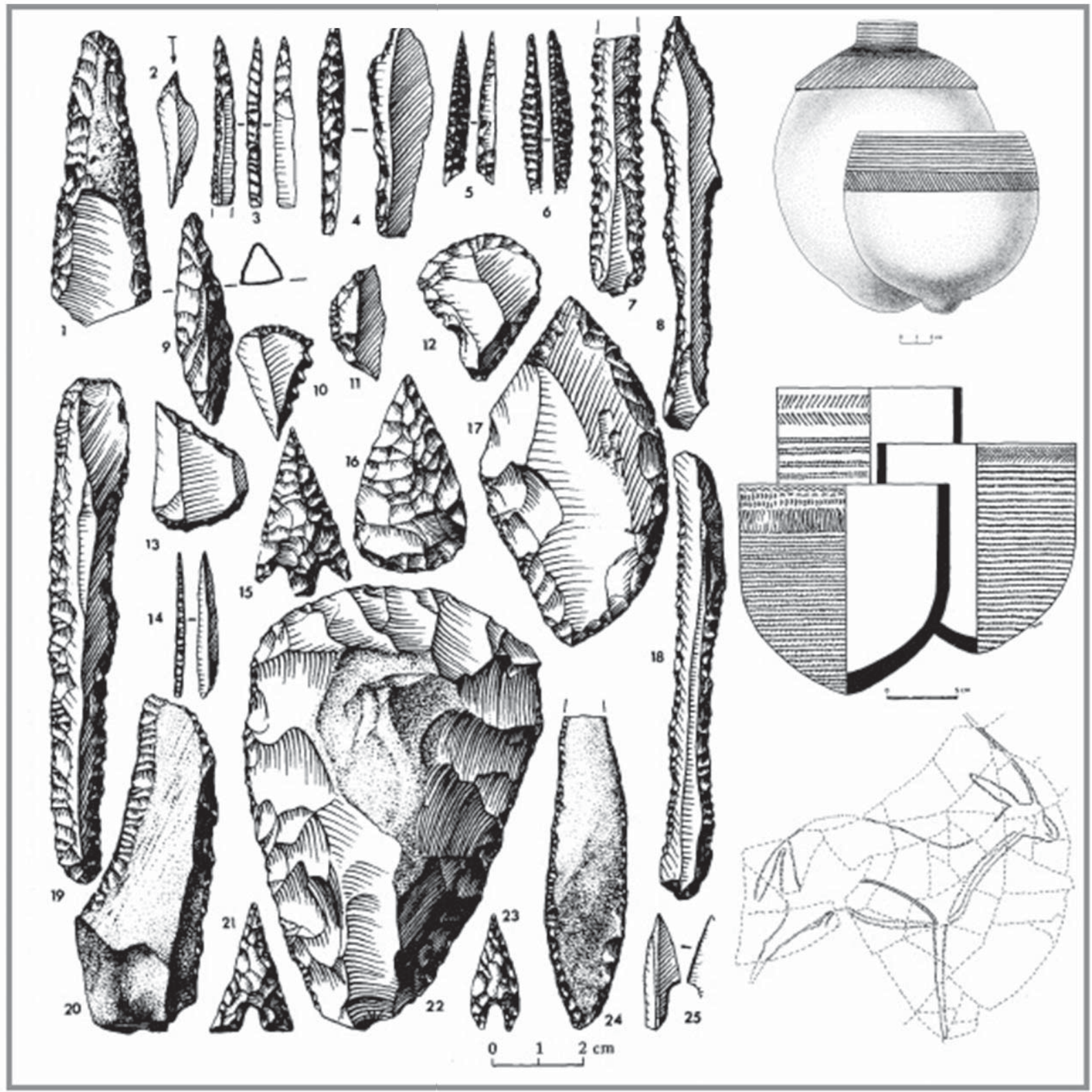

Рис. 7. Археологические находки сахарского неолита капсийской традиции (по: Camps, 1982, p.598-600, 602, fig. 8,13-16; с изменениями).

Fig. 7. Archaeological finds of the Saharan Neolithic of the Capsian tradition (after: Camps, 1982, p. 598-600, 602, fig. 8.13-16; as amended).

Марокканский комплекс известен своим взаимодействием с культурой кардиальной керамики наряду с развитием собственных региональных культурных черт (Camps, 1971, 1974, 1982; Daugas et al., 2008). Каменная и костяная индустрии не очень представительны, и большинство исследований сосредоточено на керамике, на которой основана хронология неолита в Марокко (Camps, 1974, 1998). Переход к неолиту в Северо-Западном Магрибе начался примерно около 7650-7500 ${ }^{14} \mathrm{C}$ л. н., до распространения кардиальной керамики через Гибралтарский пролив (Ballout, 1969; Camps, 1971, 1974, 1982, 1998; Daugas et al., 2008; Lindstader et al., 2012; Mulazzani et al., 2015).

\section{Характеристика средиземноморского неолита}

Керамика толще европейской кардиальной керамики, орнаменты очень сложны; вазообразные сосуды с широкими венчиками, декорированные по венчику оттисками палочек или клиньев, с яйцевидным туловом и коническим, плоским или округлым дном. Орнаменты региона Телля обычно представлены оттисками гребенчатого штампа, стеблей растений и проколок. Резные орнаменты и ручки широко распространены (Camps- 


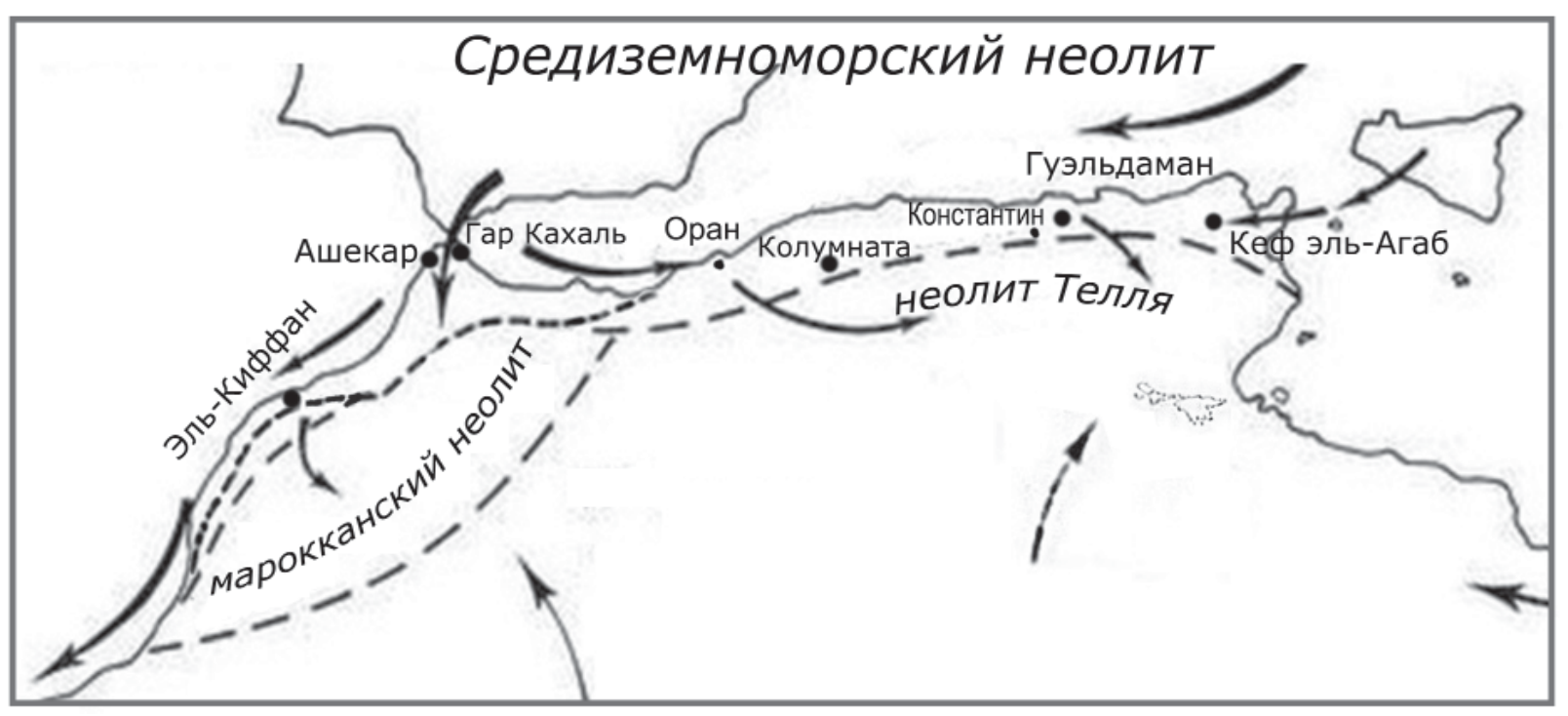

Рис. 8. Карта распространения средиземноморского неолита (по: Camps, 1982, 1998; с изменениями).

Fig. 8. Map of the Mediterranean Neolithic (after: Camps, 1982, 1998; as amended).

Fabrer, 1966; Camps, 1974, 1998; Mulazzani et al., 2015; Kherbouche, 2014). Распространение кардиальной керамики в северное Марокко и на северо-запад Алжира в основном отмечено использованием оттисков Cardium edule и других моллюсков, а также изготовлением сосудов с ручками (рис. 9) (Camps-Fabrer, 1966; Camps, 1971, 1974, 1982, 1998; Daugas et al., 2008; Lindstader et al., 2012; Mulazzani et al., 2015; Kherbouche, 2014).

Каменная индустрия считается грубой и состоит из зубчатых орудий, пластин, лезвий, геометрических микролитов (сегментов, пластин с усечением и трапеций), проколок, долот и скребков. Каменный инвентарь основан на традициях иберо-маврской культуры, с изменениями формы и размеров орудий (скребки, зубчатые орудия, сверла, пластины с ретушью, сегменты), редкими неолитическими чертами являются такие изделия как прямоугольные микролиты, наконечники стрел и полированные топоры (Camps, 1971, 1974 , 1982). Наконечники стрел и бифасиальные листовидные наконечники встречаются редко, они считаются объектами импорта или обмена, что подтверждено для обсидиановых изделий с островов Пантеллерия и Липари, а также крупных листовидных наконечников марокканского побережья (рис. 9), изготовленных из привозного белого кремня (Camps, 1963, 1971, 1982, 1998; Costa, 2006, 2007; Freund, 2017).

Костяная индустрия и украшения значительно развились, но, похоже, они являются результатом развития наследия иберо-маврской культуры; разнообразие и изобилие костяных изделий подтверждают ее неолитический характер (Camps, 1982). Различные минералы (оксид железа, гематит, сульфид) использовались в качестве красящих пигментов для раскраски тела (Camps, 1974, 1982). Захоронения «неолитических мехтоидов», представленные в Мехта эль-Арби, показывают, что неолит сохранил иберо-маврскую традицию удаления зубов (Camps, 1974).

Наличие керамики и зерна являются показателями использования растений. Имеются свидетельства земледелия в Марокко (Каф Тахт эль-Гар) и Алжире (пещера Гуэльдаман), где были обнаружены обгоревшие зерна пшеницы двузернянки (Triticum dicoccum) (Camps, 1971, 1974, 1982; Ballouche, Marinval, 2003; Kherbouche et al., 2014; Mulazzani et al., 2015). Мясную пищу получали в ходе охоты на туров, антилоп, муфлонов, кабанов и даже слонов. Морские моллюски широко употреблялись в пищу на побережье в период неолита, как и наземные моллюски в удаленных от моря районах. Технический прогресс в средствах передвижения и навигации позволил развить морское рыболовство, о чем свидетельствуют костные остатки крупных рыб, таких как тунец, обнаруженные на прибрежных поселениях в Оране (Западный Алжир) и в Восточном Марокко (Camps, 1974; Lindstater et al., 2012). Первые следы доказанного одомашнивания связаны с козами и датируются второй половиной VI тыс. 


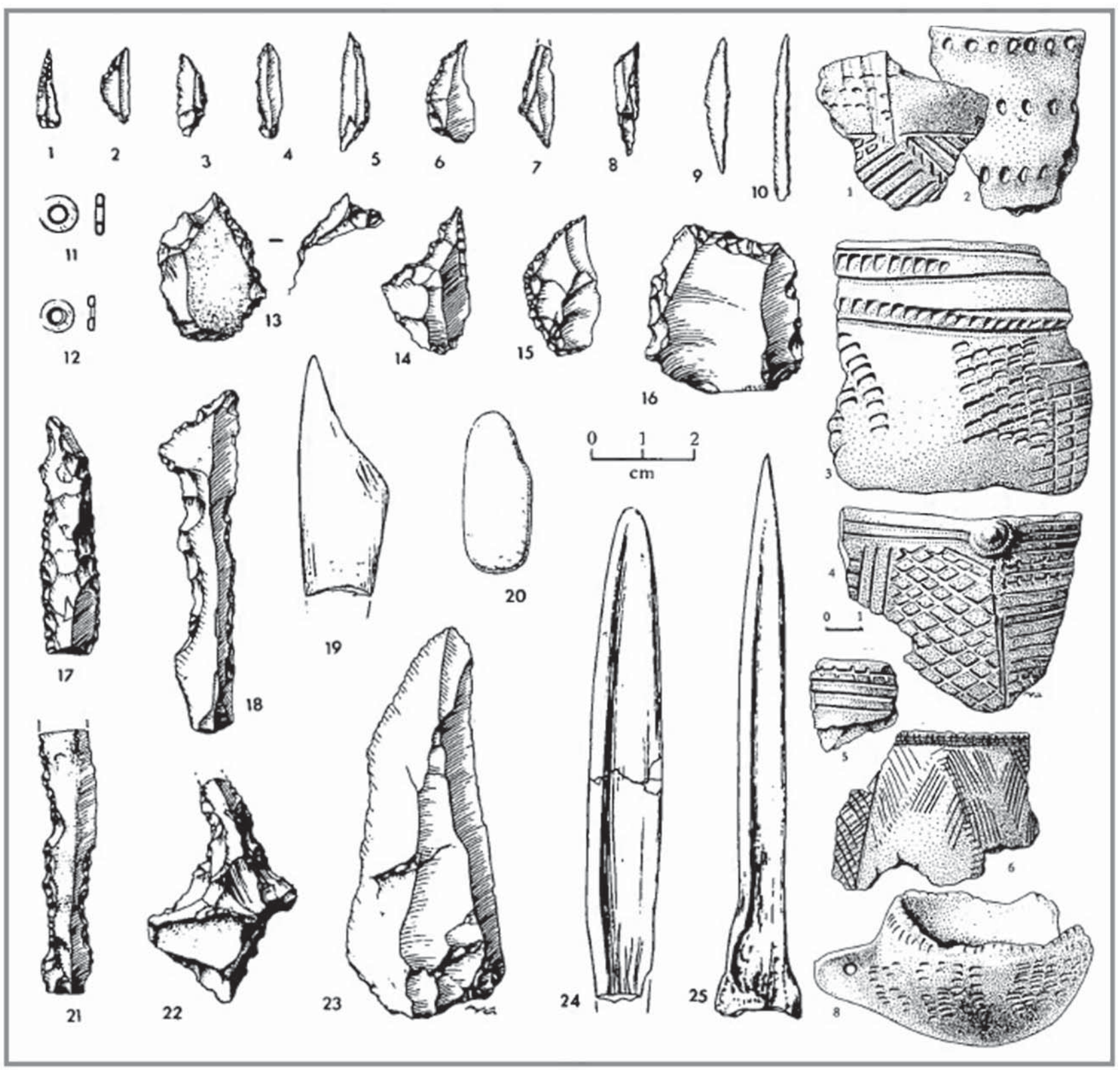

Рис. 9. Археологические находки из Уади-Геттара и орнаментированная керамика из Орана (Северо-Западный Алжир) (по: Camps, 1982, p. 584-585, fig. 8,9-10; с изменениями).

Fig. 9. Archaeological finds from Ouadi Guettara and ornamented pottery from Oran (the North West Region of Algeria) (after: Camps, 1982, p. 584-585, fig. 8.9-10; as amended).

до н.э., после появления кардиальной керамики в Северной Африке. О скотоводстве свидетельствуют кости овец, коз, крупного рогатого скота и свиней (Camps, 1974, 1982; Ballouche, Marinval, 2003; Mulazzani et al., 2015).

\section{Выводы}

Процесс неолитизации Африки остается малопонятным из-за малого числа исследований. Большинство памятников Сахары представляют собой развеянные объекты, по которым трудно судить об однородности находок и на которых очень плохие условия для сохранности органических материалов и датировки. Также своеобразна история иссле- дований, многие районы остаются закрытыми для археологов из-за конфликтов или других проблем. Наконец, из-за некоторых данных, в частности очень старых датировок неолита в определенных регионах, которые очевидно являются сильно спорными, существование реального очага неолитизации в Африке также все еще обсуждается, даже если это очень вероятно. Неолит Северной Африки демонстрирует социокультурную сложность, в которой способы распространения неолитических черт и природа региональных контактов еще не полностью поняты. 
Исследования характерных черт этого периода показали:

- наличие трех очень разных неолитических зон;

- обширную сеть взаимодействий между различными региональными культурами;

- разнообразие региональных культурных черт;

- тенденции адаптации к окружающей среде и специализации (скотоводы, рыбаки, земледельцы, художники);

- малочисленность данных об одомашнивании животных и особенно о земледелии;
- особая тенденция в эстетическом аспекте каменной и костяной индустрий и присутствие наскального искусства и мелкой пластики в регионах Сахары и капсийской традиции.

Несмотря на сравнительно старые данные, представленные в статье, эти материалы остаются важными и беспрецедентными исследованиями, предпринятыми до сих пор в регионе Северо-Западной Африки. Возобновленные в последние годы систематические раскопки памятников обещают предоставить больше информации о богатстве доисторических материалов Северной Африки.

\section{ЛИТЕРАТУРА}

Aumassip G. La néolithisation au Sahara // Cahiers O.R.S.T.O.M. Série. Géol. 1984. Vol. XIV, no 2. P. 199-200.

Aumassip G. Le Bas-Sahara dans la Préhistoire. Préface de Gabriel Camps. Paris: Editions du Centre National de la Recherche Scientifique, 1986. 626 p.

Aumassip G. Bas-Sahara (Préhistoire) // Encyclopédie berbère. 1991. No. 9. P. 1365-1371.

Aumassip G. Le milieu et les hommes au sud de la méditerranée après le Pléniglaciaire // El mon mediterrani desprès del pleniglacial (18000-12000 BP) / Éditeur scientifique J.M. Fullola \& N. Soler. Girona: Museu d'Arqueologia de Catalunya. 1997a. P. 43-56.

Aumassip G. L'émergence précoce du Néolithique au Sahara // Pour la science. 1997b. No 234. P. 55-63. $224 \mathrm{p}$.

Aumassip G. L'Algérie des premiers hommes. Paris: Éditions de la Maison des sciences de l'homme, 2001.

Aumassip G. Prehistoire du Sahara et de ses abords: Au temps des chasseurs, le paleolithique. Paris: Maisonneuve \& Larose, 2004. 381 p. $544 \mathrm{p}$.

Ballout L. Préhistoire de l'A frique du Nord, Essai de chronologie. Paris: Arts et métiers graphiques, 1955.

Ballout L. Réflexions sur le problème du peuplement préhistorique de l'Archipel Canarien // Anuario de Estudios Atlânticos. 1969. Vol. 1, no 15. P. 133-145.

Balout L. Chronologie absolue et préhistoire saharienne // Revue de l'Occident musulman et de la Méditerranée. 1972. No 11. P. 13-19.

Ballouche A., Marinval P. Données palynologiques et carpologiques sur la domestication des plantes et l'agriculture dans le Néolithique ancien du Maroc septentrional. Le site de Kaf Taht El-Ghar // Archeosciences, revue d'Archéométrie. 2003. No 27. P. 49-54.

Bencherif S. L'élevage pastoral et la céréaliculture dans la steppe algérienne Évolution et possibilités de développement. Thèse. Paris, 2011. 269 p. $366 \mathrm{p}$.

Camps G. Les civilisations préhistoriques de l'Afrique du Nord et du Sahara. Paris: Doin Editeurs, 1974.

Camps G. Origines de la domestication en Afrique du Nord et au Sahara // Le sol, la parole et l'écrit: 2000 ans d'histoire africaine / Mélanges en hommage à R. Mauny. T. II. Paris: Société française d'histoire d'outremer, 1981. P. 547-560.

Camps $G$. The beginning of pastoralism and cultivation in north-west Africa and the Sahara, origin of the Berbers // The Cambridge history of Africa / Edited by J. Desmond Clark. Vol. 1. From the earliest times to 500 BC. Cambridge: Cambridge University Press, 1982. P. 548-623.

Camps G. Le Néolithique méditerranéen: techniques et genres de vie. Aix-en-Provence, Édisud, 1998. 95 p.

Camps G., Delibria G., Thommeret J. Chronologie absolue et succession des civilisations préhistoriques dans le Nord de l'Afrique // Libyca. 1988. T. 16. P. 9-28.

Camps-Fabrer H. Matière et art mobilier dans la préhistoire nord-africaine et saharienne. Paris: Arts et métiers graphiques, $1966.573 \mathrm{p}$. 
Camps-Fabrer H., Camps G. Perspectives et orientation des recherches sur le Néolithique saharien // Revue de l'Occident musulman et de la Méditerranée. 1972. No 11. P. 21-30.

Chavaillon N. Note sur quelques dates intéressant la préhistoire du Sahara Nord-Occidental // Bulletin de la Société préhistorique française. Comptes rendus des séances mensuelles. 1964. T. 61, no 4. P. 88-91.

Costa L.-J. Récents acquis sur la circulation préhistorique de l'obsidienne en Corse // Bulletin de la Société Préhistorique Française. 2006. T. 103. No 1. P. 71-85.

Costa L.-J. L'obsidienne. Un témoin d'échanges en Méditerranée préhistorique. Paris: Editions Errance, 2007. $110 \mathrm{p}$.

Daugas J.P., Idrissi A., Ballouche A., Marinval P., Ouchaou B. Le Néolithique ancien au Maroc septentrional: données documentaires, sériation typochronologique et hypothèses génétiques // Bulletin de la Société préhistorique française. 2008. T. 105, no. 4, P. 787-812.

De Contenson H. G. Camps, 'Amekni, Néolithique ancien du Hoggar'// Syria. 1971. XLVIII. P. 243-247.

Freund K.P. A long-term perspective on the exploitation of Lipari obsidian in central Mediterranean prehistory // Quaternary International. 2017. Vol. 468. P. 109-120.

Garcea E.A.A. The Prehistory of the Sudan. Cham: Springer International Publishing, 2020. 196 p.

Gsell S. Les monuments antiques de l'Algérie. Paris: Éditeur Albert Fontemoing, 1901. T. I. 290 p.

Gsell S. Histoire Ancienne de l'Afrique du Nord. Paris: Librairie Hachette, 1918. T. I. 515 p.

Guo Z., Petite-Maire N., Kröpelin S. Holocene non-orbital climatic events in present-day arid areas of northern Africa and China // Global and Planetary Change. 2000. No 26. P. 97-103.

Hachid $M$. The domestication of sheep, goats and domestic cattle in the Maghreb and a dating for North African rock art: 8000 cal BP// Inora. 2015. No 73. P. 18-31.

Hassan F.A. Chronology of the Khartoum 'Mesolithic' and 'Neolithic' and related sites in the Sudan: statistical analysis and comparisons with Egypt // The African Archaeological Review. 1986. No 4. P. 83-102.

Honoré E. L'appropriation de la nature par l'Homme au Sahara égyptien (Gilf el-Kebir) au cours de l'optimum holocène // Afrique: Archéologie \& Arts. 2014. No 10. P. 81-83.

Hendrickx S. La chronologie de la préhistoire et des débuts de l'histoire de l'Egypte // Archéo-Nil: Revue de la société pour l'étude des cultures prépharaoniques de la vallée du Nil. 1999. No 9. P. 13-81.

Kandel A.W., Conard N.J. Production sequences of ostrich eggshell beads and settlement dynamics in the Geelbek Dunes of the Western Cape, South Africa // Journal of Archaeological Science. 2005. Vol. 32, no 12. P. 1711-1721.

Kherbouche F., Hachi S., Abdessadok S., Sehil N., Harichane Z., Merzoug S., Sari L., Fontugne M., Agsous S., Barbaza M., Roubet C. Nouvelles recherches préhistoriques dans l'Adrar Gueldamane (Akbou, Algérie): premières fouilles dans la grotte GLD1 // Actes RQM6. 2014. P. 219-228.

Lemercier $O$. Archéologie Néolithique: De la Préhistoire à l'Histoire... A l'origine de nos sociétés (120002000 avant notre ère). Un monde en mouvement: Introduction au Néolithique et introduction au cours. 2007. URL: http://ubprehistoire.free.fr/Documents\%20a\%20telecharger/Un\%20monde\%20en\%20mouvement.pdf (дата обращения: 09.05.2021).

Le Quellec J.-L. Périodisation et chronologie des images rupestres du Sahara central // Préhistoires Méditerranéennes. 2013. No 4. P. 2-45.

Linstädter J., Medved I., Solich M., Weniger G.-C. Neolithisation process within the Alboran territory: Models and possible African Impact // Quaternary International. 2012. No 274. P. 219-232.

Mulazzani S., Le Bourdonnec F.-X., Belhouchet L., Poupeau G., Zoughlami J., Dubernet S., Tufano E., Lefrais $Y$., Khedhaier R. Obsidian from the epipalaeolithic and Neolithic eastern Maghreb: a view from the Hergla context (Tunisia) // Journal of Archaeological Science. 2010. Vol. 37, no 10. P. 2529-2537.

Rahmani N. Le capsien typique et le capsien supérieur: Evolution ou contemporanéité - Les données technologiques / British Archaeological Reports. International series. No 1187. Oxford: Archaeopress, 2003. 315 p.

Roubet $C$. Économie pastorale préagricole en Algérie orientale. Le Néolithique de tradition capsienne, exemple: l'Aurès. Préface du Doyen Lionel Balout. Paris: Éditions du Centre National de la Recherche Scientifique, $1979.595 \mathrm{p}$.

Sahed A.T. First neolithic manifestations in Algeria: Datas \& problematic // Bakhta Mokrante. Papers of the workshop: The city and the countryside in antique Algeria. Mscara: Edts. Publications of the University of Mscara, 2014. P. 176-193. [In Arabic].

Sahnouni M. The prehistory. Ben Aknoun: University Office of Publications, 1999. 165 p. (in Arabic).

Senécal P. Histoire de l'interprétation de la transition néolithique: Évolution des théories, modèles et hypothèses. Université de Montréal: Mémoire de maîtrise ès sciences en anthropologie, 2010. 197 p. 
Vernet $R$. Le Sahara préhistorique entre Afrique du Nord et Sahel: état des connaissances et perspectives // Du Nord au Sud du Sahara. Cinquante ans d'archéologie française en Afrique de l'Ouest et au Maghreb. Bilan et perspectives / Éditeurs scientifiques André Bazzana \& Hamady Bocoum. Paris: Éditions Sépia, 2004. P. 89-100.

Wengler L., Vernet J.L., Michel P. Evénements et chronologie de l'Holocène en milieu continental au Maghreb. Les données du Maroc oriental // Quaternaire. 1994. V. 5, no 3-4. P. 119-134.

Zammit J. La préhistoire de l'Afrique du Nord, cette inconnue // L'Algérianiste. 1984. No 25. P. 18-25.

\section{Информация об авторах:}

Си-Аммур Софиан, аспирант, Казанский (Приволжский) федеральный университет (г. Казань, Россия); sofiane.siammour@gmail.com

Недашковский Леонард Федорович, доктор исторических наук, доцент, Казанский (Приволжский) федеральный университет (г.Казань, Россия); Leonard.Nedashkovsky@kpfu.ru; leonnedashkovsky@mail.ru

\section{About the Authors:}

Si-Ammour Sofiane. Post-graduate student. Kazan (Volga region) Federal University. Kremlyovskaya Str., 18, 420008, Kazan, Russian Federation; sofiane.siammour@gmail.com

Nedashkovsky Leonard F., Doctor of Historical Sciences, Professor. Kazan (Volga region) Federal University. Kremlyovskaya Str., 18, 420008, Kazan, Russian Federation; Leonard.Nedashkovsky@kpfu.ru; leonnedashkovsky@mail.ru

Статья поступила в журнал 01.10.2021 г. Статья принята к публикации 01.12.2021 г. Авторы внесли равноценный вклад в работу. 